\title{
COMMENTARY
}

\section{Stem cell therapy for diabetes: do we need to make beta cells?}

\author{
Christopher J Burns, Shanta J Persaud and Peter M Jones \\ Beta Cell Development and Function Group, King's College London, Hodgkin Building, Guy's Campus, London SE1 1UL, UK \\ (Requests for offprints should be addressed to C J Burns; Email: chris.burns@kcl.ac.uk)
}

\begin{abstract}
Type 1 diabetes can now be ameliorated by islet transplantation, although this treatment is restricted by the insufficient supply of islet tissue. The need for an essentially limitless supply of a substitute for primary human islets of Langerhans has led to research into the suitability of stem/progenitor cells to generate insulin-producing cells to use in replacement therapies for diabetes. Although there has been much research in this area, an efficient and reproducible protocol for the differentiation of stem cells
\end{abstract}

into functional insulin-secreting $\beta$-cells that are suitable for transplantation has yet to be reported. In this commentary we examine the minimum requirements for replacement $\beta$-cells and outline some of the potential sources of these cells. We also argue that the generation of the 'perfect' beta-cell may not necessarily lead to the most suitable tissue for transplantation.

Journal of Endocrinology (2004) 183, 437-443

\section{Introduction}

Type 1 (insulin-dependent) diabetes is a chronic disease affecting genetically predisposed individuals, in which insulin-secreting $\beta$-cells within pancreatic islets of Langerhans are selectively and irreversibly destroyed by autoimmune assault. For over 80 years the main therapeutic approach to insulin-dependent diabetes has been confined to treating the symptoms by insulin replacement. Recently, significant advances in the transplantation of human primary islets of Langerhans into individuals with Type 1 diabetes has largely removed this insulin dependency (Shapiro et al. 2000, Ryan et al. 2001). However, the application of this treatment is restricted by the very limited availability of primary human islets from heartbeating donors, and what is now required is an essentially limitless supply of a physiologically competent substitute for primary human islets of Langerhans.

\section{Beta cells from stem cells}

Recent advances in stem cell biology raise the possibility of offering personalised therapy to people with Type 1 diabetes by applying cloning strategies to create immunologically autologous embryonic stem (ES) cells from which to generate functional pancreatic $\beta$-cells for transplantation therapy. Therapeutic cloning involves taking the nucleus from one of the patient's somatic cells, inserting it into an enucleated human egg and allowing it to develop into a blastocyst. The inner cell mass of the blastocyst is used to generate pluripotent ES cell lines, which can be expanded in vitro to produce the billions of cells required for transplantation therapy. Alternatively, the stem cell populations may be derived by expansion of tissue stem cells from biopsy samples of the patient's pancreas, liver, or bone marrow. Whatever their origin, the stem cells will be differentiated into insulin-producing cells, and these will be formed into islet-like structures for transplantation into the patient to cure their diabetes.

Although seemingly idealistic, many aspects of this scenario are already possible. Human embryos have been cloned using nuclei from somatic cells (Hwang et al. 2004), although there are unresolved ethical and legal issues with this process. Pluripotent human ES cell lines have been generated from both cloned and normal blastocysts, and the number of cell lines available to researchers is on the increase (Cowan et al. 2004). We have the ability to form islet-like structures from $\beta$-cell populations in vitro (Hauge-Evans et al. 1999), and there are now numerous instances (>250 in over 25 centres worldwide) of islet transplantation in people with Type 1 diabetes. However, the pivotal, and as yet unresolved, stage in this novel therapeutic process is the efficient and reproducible differentiation of stem cells into functional insulin-secreting $\beta$-cells. 


\section{Minimum requirements for replacement $\beta$-cells}

Any substitute for primary islets of Langerhans will require some minimum essential properties if it is to be of use in the transplantation therapy of diabetes.

First, vast numbers of replacement $\beta$-cells will be required to make any significant therapeutic impact. Thus, current transplantation protocols use up to $1 \times 10^{6}$ primary human islets per recipient, equivalent to approximately $2-4 \times 10^{9} \beta$-cells. If we multiply this by the number of potential recipients with Type 1 diabetes (up to $\sim 10^{5}$ in the UK; $\sim 10^{6}$ in the USA), the scale of the problem becomes apparent. Although a recent report identified pre-existing $\beta$-cells as the source of new $\beta$-cells in normal growth and development (Dor et al. 2004), mature $\beta$-cells have a very low proliferative capacity (Swenne 1992). As a result, the large numbers of cells required will have to be derived from a proliferative precursor population that can be expanded considerably in vitro before differentiation into the mature $\beta$-cell phenotype. The ability of stem cells of adult or embryonic origin to replicate and to differentiate into a range of tissue types makes them attractive candidates for producing replacement $\beta$-cells.

Secondly, the replacement cells must have the ability to synthesise, store and release insulin when it is required, primarily in response to changes in the ambient glycaemia. Pancreatic $\beta$-cells have evolved intricate mechanisms which allow them to monitor and respond rapidly to changes in circulating nutrients, and these mechanisms are now reasonably well understood (reviewed by Jones \& Persaud 1998). Given the complexity of the $\beta$-cell glucose-induced stimulus-response coupling mechanism (Fig. 1), it is perhaps not surprising that attempts to engineer some of these response elements into substitute $\beta$-cells have so far failed to produce cells with normal secretory phenotypes (reviewed by Persaud 1999).

Thirdly, the proliferative capacity of the replacement cells must be tightly controlled to avoid the development of hyperinsulinaemic hypoglycaemia as the $\beta$-cell mass expands in vivo. This is not a problem when transplanting non-proliferative primary $\beta$-cells, but it has the potential to cause profound problems when using cells derived from proliferative precursors unless precautions are taken to exclude proliferative cells from the transplant material. In our opinion, this precludes the clinical use of the many transformed, proliferative insulin-secreting cell lines that have been reported (see Persaud 1999), and these will not be considered further here.

Finally, the transplanted cells must avoid destruction by the recipient's immune system. The immunology of transplant rejection is a complex area and various strategies are being adopted to avoid the problems of immune responses without resorting to global and life-long immunosuppression. There are, however, specific problems when considering $\beta$-cell transplantation into patients with Type 1 diabetes since their immune systems are programmed to destroy primary $\beta$-cells, and will presumably target even the immunologically homologous $\beta$-cell replacements that would be derived by therapeutic cloning of embryonic stem cells. One way of circumventing this problem may be to generate insulin-secreting cells that possess the functional phenotype of $\beta$-cells but which are developmentally and immunologically distinct from primary $\beta$-cells and so may evade the immune assault without immunosuppression.

\section{Potential sources of stem cells}

A variety of tissues harbour progenitor or stem cells (summarised in Table 1), and if it were possible to isolate and expand these cells in vitro and then differentiate them to adopt a $\beta$-cell phenotype, they would be a potential source of substitute tissue for transplantation. The pancreas is an obvious source tissue and a number of studies have suggested the existence of stem cells within the pancreas that can be induced to adopt some elements of a $\beta$-cell phenotype (Bonner-Weir et al. 2000, Hunziker \& Stein 2000, Ramiya et al. 2000, Habener 2001, Zulewski et al. 2001, Abraham et al. 2002, Seaberg et al. 2004). Progenitor cells from tissues other than the pancreas have also received considerable attention. Thus, liver and pancreas have a common embryonic origin, share many phenotype-maintaining transcription factors and both are equipped to respond to circulating glucose concentrations. Furthermore, there is evidence demonstrating transdifferentiation of cells from the liver towards a $\beta$-cell phenotype (Ferber et al. 2000, Susuki et al. 2002, Yang et al. 2002, Horb et al. 2003, Kojima et al. 2003, Tuch et al. 2003). Similarly, it has been reported that stem cells derived from bone marrow can be differentiated in vitro (Jahr \& Bretzel 2003) and in vivo (Ianus et al. 2003) into insulin-expressing cells, although these progenitor cells are unlikely to be the highly proliferative haematopoietic stem cells (Lee \& Stoffel 2003). However, to date there is no convincing evidence that insulinproducing cells derived from pancreatic stem cells or liver progenitors can be expanded in vitro to clinically useful numbers.

Neural progenitor cells, isolated from regions within the brain, can be significantly expanded in vitro (Minger et al. 1996) and have the capacity to differentiate from their ectodermal origins into cells from all three germ layers (Clarke et al. 2002, Sang et al. 2002). This is of particular interest since all of the elements of the $\beta$-cell glucosesensing mechanism (Fig. 1) are also expressed in populations of neurons (Yang et al. 1999), as are many of the recognised transcription factors that are used to map the development of the $\beta$-cell (Wilson et al. 2003). We have recently demonstrated that rat neural stem cells can be expanded in vitro, and can be induced to express the 


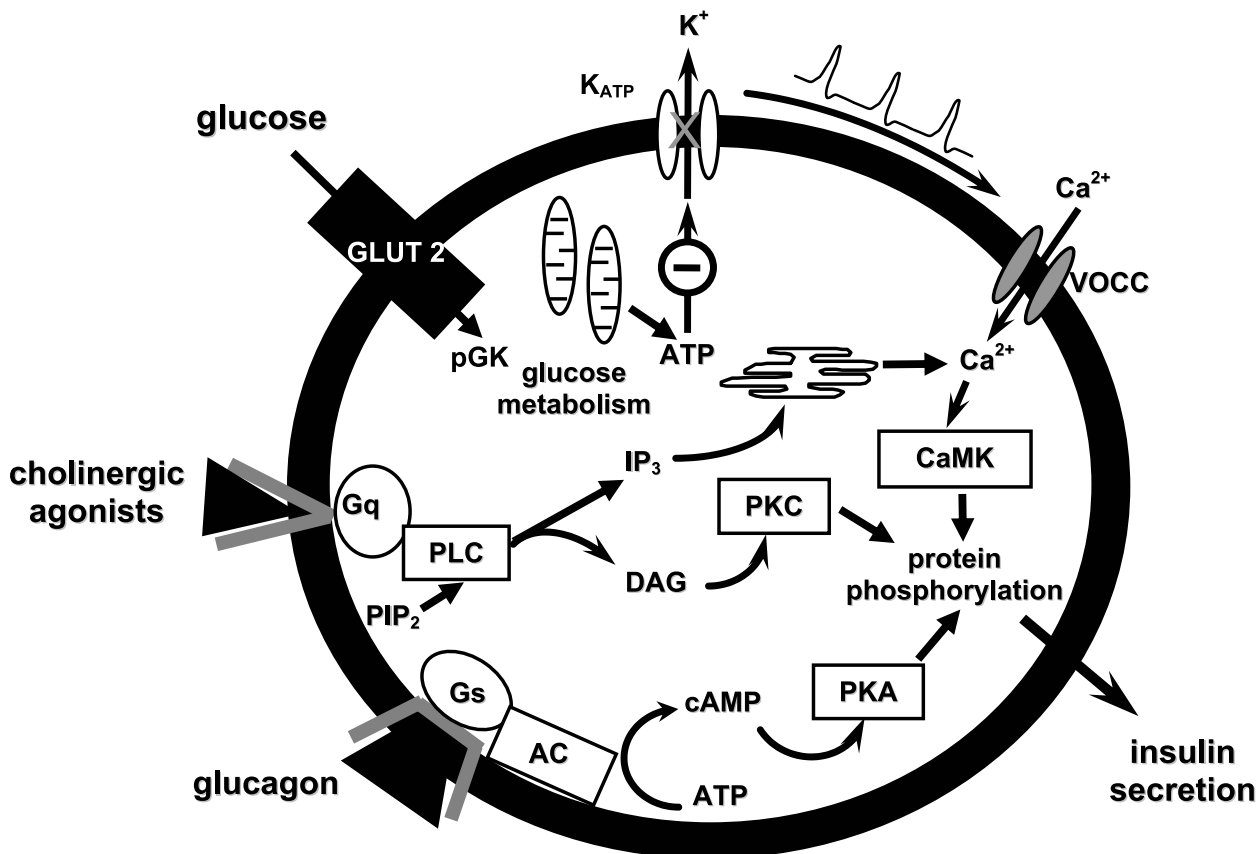

Figure 1 Stimulus-response coupling in a primary pancreatic $\beta$-cell. The figure shows a schematic representation of how a $\beta$-cell recognises changes in extracellular glucose and translates that recognition into an insulin secretory response. When extracelllular glucose increases, glucose is transported rapidly into the $\beta$-cell on the high capacity GLUT2 transporter such that cytosolic glucose mirrors plasma glucose. Inside the $\beta$-cell, glucose is rapidly phosphorylated by the pancreatic form of glucokinase (pGK) and the subsequent increase in ATP production by mitochondrial oxidative metabolism causes the closure of plasma membrane ATP-sensitive $\mathrm{K}^{+}$-channels $\left(\mathrm{K}_{\text {ATP }}\right)$, which are composed of Kir6.2 and SUR1 subunits. The reduced $\mathrm{K}^{+}$efflux leads to the depolarisation of the $\beta$-cell which, in turn, causes the opening of voltage-operated $\mathrm{Ca}^{2+}$ channels (VOCC) in the plasma membrane. Extracellular $\mathrm{Ca}^{2+}$ $\left(\left[\mathrm{Ca}^{2+}\right]_{\mathrm{e}}\right)$ enters through the VOCC and the consequent elevations in intracellular $\mathrm{Ca}^{2+}\left(\left[\mathrm{Ca}^{2+}\right]_{\mathrm{i}}\right)$ initiate an insulin secretory response by activating a number of $\mathrm{Ca}^{2+}$-sensitive processes, including protein kinases such as CaMK (calcium/calmodulin-dependent protein kinase) and protein kinase C (PKC), phospholipases and exocytotic elements. The figure also shows how insulin secretion from the $\beta$-cell can be modulated by non-nutrient secretagogues such as glucagon (and related peptides) and the cholinergic agonist, acetylcholine. Glucagon binds to a G-protein-associated cell surface receptor coupled to adenylate cyclase (AC), resulting in an increase in CAMP and an activation of protein kinase A (PKA). Acetylcholine binds to a G-protein-associated cell surface receptor coupled to phospholipase C (PLC) which liberates inositol trisphosphate $\left(\mathrm{IP}_{3}\right)$ and diacylglycerol (DAG) from membrane phospholipids. $\mathrm{IP}_{3}$ releases $\mathrm{Ca}^{2+}$ from the endoplasmic reticulum and this increase in $\left[\mathrm{Ca}^{2+}\right]_{i}$ activates CaMK. DAG, either alone or together with $\mathrm{Ca}^{2+}$, activates PKC. The activation of these protein kinases leads to protein phosphorylation, the stimulation of exocytotic events and ultimately insulin secretion.

insulin gene and respond metabolically to nutrients and sulphonylureas (Burns et al. 2003). The ability of neural cells to express the insulin gene is consistent with reports of transient expression of preproinsulin in the fetal brain during development (Devaskar et al. 1993a,b).

An alternative source of highly proliferative, pluripotent cells which has received much more attention is ES cells. Derived from the inner cell mass of the blastocyst, these cells have the capacity to differentiate into all three embryonic germ layers in vitro. A large number of reports have now demonstrated that ES cells can differentiate into cells with an insulin-expressing phenotype, either by genetic manipulation or by permitting spontaneous differentiation followed by culture under selective conditions (Soria et al. 2000, Assady et al. 2001, Lumelsky et al. 2001, Hori et al. 2002, Shiroi et al. 2002, Blyszczuk et al. 2003, Moritoh et al. 2003, Miyazaki et al. 2004, Segev et al. 2004, Sipione et al. 2004). In common with studies using tissue stem cells, the cellular identity of these insulin-expressing cells is uncertain and with the lack of specific, easily identifiable markers of a mature $\beta$-cell, the possibility remains that these cells are not fully mature $\beta$-cells but instead are a phenotypically similar population of cells, perhaps of neuroectodermal (Lumelsky et al. 2001, Burns et al. 2003) or extra-embryonic (Houard et al. 2003) origin. 

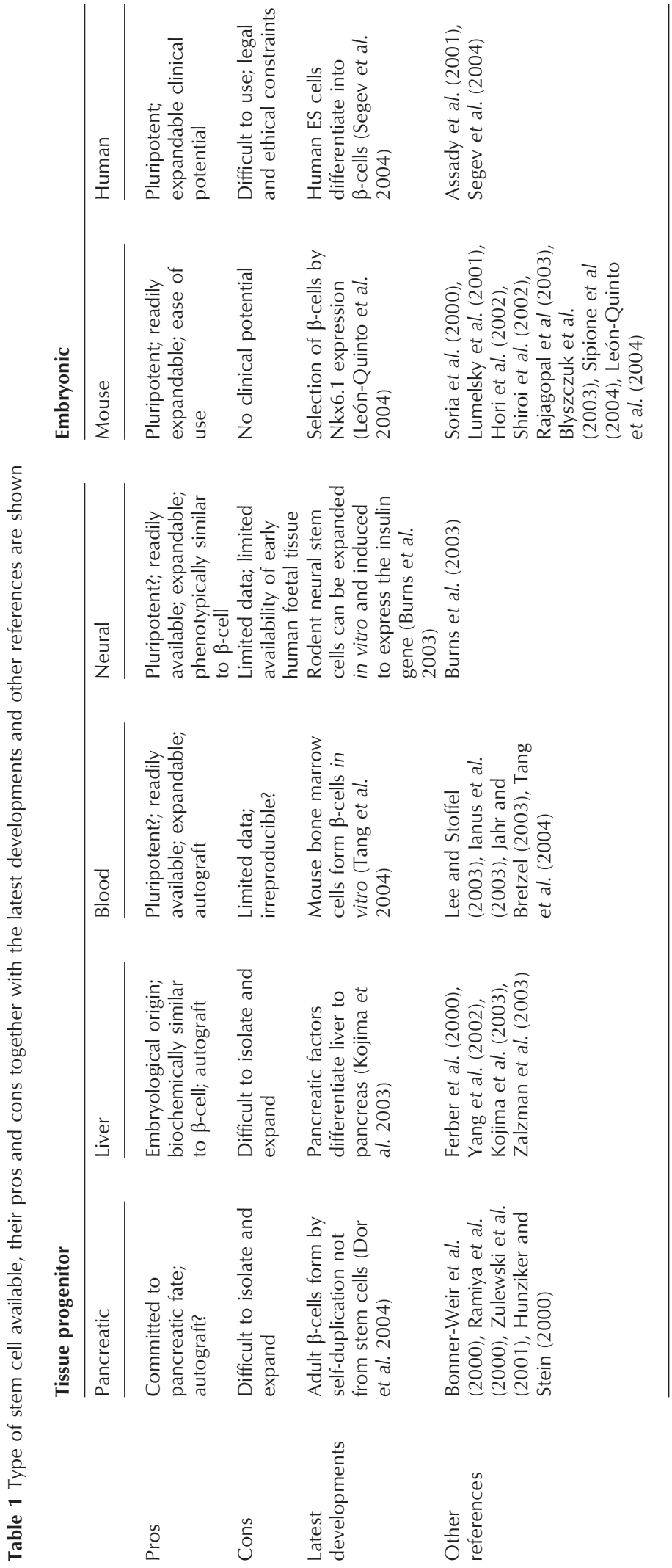


\section{Stem cell therapy for diabetes}

Despite considerable efforts over the past 4 years, we still lack the means for reproducibly and efficiently differentiating stem cell populations into functional $\beta$-cells. There are probably many reasons why this has so far proved an elusive goal but, in our view, there are two main issues to be resolved.

\section{(i) Which stem cells?}

Perhaps the most important issue is the choice of the appropriate starting material. Research efforts are currently divided between embryonic and tissue stem cells as potential therapeutic progenitor cells. The proliferative capacity of ES cells is attractive, but their pluripotency may be a disadvantage. Differentiation of pluripotent ES cells generally produces a mixture of many different cell types and, in the absence of reliable selection procedures, this process cannot yet produce the homologous populations of fully differentiated $\beta$-cells required for transplantation therapy. Tissue stem cells are further down the developmental pathway than ES cells, and so may be lineage-restricted to some extent, which may make it easier to drive them down particular developmental lineages. However, this experimental advantage is currently outweighed by the limited replicative potential of tissue stem cell populations in vitro. There may also be more subtle differences in the developmental potential of different stem cell populations. It is becoming evident that ES cell lines, both mouse and human, are not identical in their phenotype, in their culture requirements in vitro, or in their propensity to differentiate down particular lineages. This implies that some cell lines may be more appropriate than others from which to generate $\beta$-cells. If so, we may need to apply differentiation protocols to numerous ES cell lines to determine which line, if any, is the best starting material. The generation of large numbers of different human ES cell lines, and the development of centralised 'stem cell banks' to characterise, store and distribute the cells should facilitate this process.

\section{(ii) Do we need to make $\beta$-cells?}

The second question is whether we need to recapitulate in vitro the precise developmental pathway that leads to the differentiation of $\beta$-cells in vivo. Many current studies, particularly those using ES cells, try to map their experimental protocols on to the known developmental pathways of pancreatic endocrine cells. However, the complex sequence of developmental events directing duodenal endoderm towards an insulin-expressing $\beta$-cell phenotype in vivo are the result of millions of years of evolutionary selection, driven by environmental pressures rather than by conscious design. There is some evidence that it may be possible to employ conscious design to arrive at the same end-point by a less circuitous route. Thus, it has been suggested that the pathways of $\beta$-cell differentiation in vitro may differ significantly from those in vivo (Houard et al. 2003) and mouse ES cells are reported to differentiate into endocrine cells without PDX-1 (pancreatic duodenal homeobox-1) expression (Moritoh et al. 2003), although this is essential in vivo (Scharfmann 2000). It is also possible that current in vitro differentiation protocols do not generate $\beta$-cells, but, instead, cells that have some phenotypic and functional similarity to authentic $\beta$-cells. For example, it has been suggested that a neural fate is a default pathway for differentiation of ES cells (Tropepe et al. 2001), and the application of culture conditions selective for nestinpositive precursors (Lumelsky et al. 2001) leads to insulin expression in cells with a neuronal phenotype (Sipione et al. 2004). These observations are consistent with our demonstration that neural stem cells can be induced to express mRNAs encoding insulin and elements associated with $\beta$-cell function, since these ectodermally derived cells are unlikely to be authentic $\beta$-cells. An alternative developmental origin for insulin-expressing cells could be the visceral endoderm of the yolk sac (Rau et al. 1989, McGrath \& Palis 1997). Visceral endoderm develops initially in a similar manner to embryonic endoderm, and primitive endodermal cells are localised to the periphery of EBs (embryoid bodies) during differentiation of mouse ES cells (Murray \& Edgar 2001). It has, therefore, been suggested that the insulin-expressing cells generated during EB formation are from visceral endoderm, since they are located almost exclusively in the outer layer of the EB (Houard et al. 2003). In the absence of specific and highly expressed markers for authentic $\beta$-cells it is difficult to determine unambiguously the origin of insulin-expressing cells generated in vitro from pluripotent progenitor populations. In any event, in our opinion, the precise developmental identity of the cells used for transplantation therapy may not be important so long as they offer an expandable population of cells that fulfils the functional criteria of replacement $\beta$-cells.

\section{Conclusion}

Type 1 diabetes is now curable by transplantation therapy, and stem cells offer a potential starting material from which to generate the large numbers of cells required. To date, most efforts have attempted to drive pluripotent stem cells down an endodermal, pancreatic, endocrine lineage but we suggest that it may not matter whether the replacement cells are developmentally authentic pancreatic $\beta$-cells as long as their functional phenotype is sufficient to produce physiological patterns of insulin secretion. Indeed, there is every expectation that the immune system in the transplant recipient with Type 1 diabetes is primed selectively to destroy even immunologically autologous pancreatic $\beta$-cells. It may, therefore, 
be a more sensible long-term strategy to focus efforts on generating populations of cells that possess the essential attributes of $\beta$-cells but which will not be recognised as $\beta$-cells by the recipient's immune system.

\section{Acknowledgements}

Our work on stem cells has been supported by Diabetes UK, the Juvenile Diabetes Research Foundation and the EU Framework V programme. C J B is a Diabetes Research and Wellness Foundation Fellow. The authors declare that there is no conflict of interest that would prejudice the impartiality of this scientific work.

\section{References}

Abraham EJ, Leech CA, Lin JC, Zulewski H \& Habener JF 2002 Insulinotropic hormone glucagon-like peptide-1 differentiation of human pancreatic islet-derived progenitor cells into insulin-producing cells. Endocrinology 143 3152-3161.

Assady S, Maor G, Amit M, Itskovitz-Eldor J, Skorecki KL \& Tzukerman M 2001 Insulin production by human embryonic stem cells. Diabetes 50 1691-1697.

Blyszczuk P, Czyz J, Kania G, Wagner M, Roll U, St Onge L \& Wobus AM 2003 Expression of Pax4 in embryonic stem cells promotes differentiation of nestin-positive progenitor and insulin-producing cells. PNAS 100 998-1003.

Bonner-Weir S, Taneja M, Weir GC, Tatarkiewicz K, Song KH, Sharma A \& O'Neil JJ 2000 In vitro cultivation of human islets from expanded ductal tissue. PNAS 97 7999-8004.

Burns CJ, Minger SL, Hall S, Roderigo-Milne H, Ramracheya RD, Persaud SJ \& Jones PM 2003 Generating insulin expressing cells from neural stem cells. Diabetologia 46 A174.

Clarke DL, Johansson CB, Wilbertz J, Veress B, Nilsson E, Karlstrom H, Lendahl U \& Frisen J 2002 Generalized potential of adult neural stem cells. Science 288 1660-1663.

Cowan CA, Klimanskaya I, McMahon J, Atienza J, Witmyer J, Zucker JP, Wang S, Morton CC, McMahon AP, Powers D \& Melton DA 2004 Derivation of embryonic stem-cell lines from human blastocysts. New England Journal of Medicine 350 1353-1356.

Devasker SU, Sadiq HF, Holtzclaw L \& George M 1993a The developmental pattern of rabbit brain insulin and insulin-like growth factor receptor expression. Brain Research 605 101-109.

Devasker SU, Singh BS, Carnaghi LR, Rajakumar PA \& Giddings SJ $1993 b$ Insulin II gene expression in rat central nervous system. Regulatory Peptides 48 55-63.

Dor Y, Brown J, Martinez OI \& Melton DA 2004 Adult pancreatic $\beta$-cells are formed by self-duplication rather than stem-cell differentiation. Nature 429 41-46.

Ferber S, Halkin A, Cohen H, Ber I, Einav Y, Goldberg I, Barshack I, Seijffers R, Kopolovic J, Kaiser N \& Karasik A 2000 Pancreatic and duodenal homeobox gene 1 induces expression of insulin genes in liver and ameliorates streptozotocin-induced hyperglycemia. Nature Medicine 6 568-572.

Habener J 2001 Multipotential nestin-positive stem cells isolated from adult pancreatic islets differentiate ex vivo into pancreatic endocrine, exocrine and hepatic phenotypes. Diabetes 50 521-533.

Hauge-Evans A, Squires PE, Persaud SJ \& Jones PM 1999 Pancreatic $\beta$-cell-to- $\beta$-cell interactions are required for integrated secretory responses to nutrient stimuli: enhanced $\mathrm{Ca}^{2+}$ and insulin secretory responses of MIN6 pseudoislets. Diabetes 48 1402-1408.

Horb M, Shen CN, Tosh D \& Slack JMW 2003 Experimental conversion of pancreas to liver. Current Biology 13 105-115.
Hori Y, Rulifson IC, Tsai B, Heit JJ, Cahoy JD \& Kim SK 2002 Growth inhibitors promote differentiation of insulin-producing tissue from embryonic stem cells PNAS 99 16105-16110.

Houard N, Rousseau GG \& Lemaigre FP 2003 HNF-6-independent differentiation of mouse embryonic stem cells into insulin-producing cells. Diabetologia 46 378-385.

Hunziker E \& Stein M 2000 Nestin-expressing cells in the pancreatic islets of Langerhans. Biochemical and Biophysical Research Communications 271 116-119.

Hwang WS, Ryu YJ, Park JH, Park ES, Lee EG, Koo JM, Jeon HY, Lee BC, Kang SK, Kim SJ, Ahn C, Hwang JH, Park KY, Cibelli JB \& Moon SY 2004 Evidence of a pluripotent human embryonic stem cell line derived from a cloned blastocyst. Science $\mathbf{3 0 3}$ 1669-1674.

Ianus A, Holz GG, Theise ND \& Hussain MA 2003 In vivo derivation of glucose-competent pancreatic endocrine cells from bone marrow without evidence of cell fusion. Journal of Clinical Investigation 111 $843-850$.

Jahr H \& Bretzel B 2003 Insulin-positive cells in vitro generated from rat bone marrow stromal cells. Transplantation Proceedings $\mathbf{3 5}$ 2140-2141.

Jones PM \& Persaud SJ 1998 Protein kinases, protein phosphorylation and the regulation of insulin secretion from pancreatic $\beta$-cells. Endocrine Reviews 19 429-461.

Kojima H, Fujimiya M, Matsumura K, Younan P, Imaeda H, Maeda M \& Chan L 2003 NeuroD-betacellulin gene therapy induces islet neogenesis in the liver and reverses diabetes in mice. Nature Medicine 9 596-603.

Lee VM \& Stoffel M 2003 Bone marrow: an extrapancreatic hideout for the elusive pancreatic stem cell? Journal of Clinical Investigation 111 799-801.

León-Quinto T, Jones J, Skoudy A, Burcin M \& Soria B 2004 In vitro directed differentiation of mouse embryonic stem cells into insulin producing cells. Diabetologia 47 1442-1451.

Lumelsky N, Blondel O, Laeng P, Velasco I, Ravin R \& McKay R 2001 Differentiation of embryonic stem cells to insulin-secreting structures similar to pancreatic islets. Science 292 1389-1394.

McGrath KE \& Palis J 1997 Expression of homeobox genes, including an insulin promoting factor, in the murine yolk sac at the time of hematopoietic initiation. Molecular Reproduction and Development 48 145-153.

Minger SL, Fisher LJ, Ray J \& Gage FH 1996 Long-term survival of transplanted basal forebrain cells following in vitro propagation with fibroblast growth factor-2. Experimental Neurology 141 12-24.

Miyazaki S, Yamato E \& Miyazaki J-I 2004 Regulated expression of $\mathrm{pdx}-1$ promotes in vitro differentiation of insulin producing cells from embryonic stem cells. Diabetes 53 1030-1037.

Moritoh Y, Yamato E, Yasui Y, Miyazaki S \& Miyazaki JI 2003 Analysis of insulin-producing cells during in vitro differentiation from feeder-free embryonic stem cells. Diabetes 52 1163-1168.

Murray P \& Edgar D 2001 The regulation of embryonic stem cell differentiation by leukaemia inhibitory factor (LIF). Differentiation $\mathbf{6 8}$ 227-234.

Persaud SJ 1999 Pancreatic $\beta$-cell lines: their roles in $\beta$-cell research and diabetes therapy. In Advances in Molecular and Cell Biology, vol. 29: The Biology of the Pancreatic $\beta$-Cell, pp 21-46. London: JAI Press Inc.

Rajagopal J, Anderson WJ, Kume S, Martinez OI \& Melton DA 2003 Insulin staining of ES cell progeny from insulin uptake. Science 299 363.

Ramiya VK, Maraist M, Arfors KE, Schatz DA, Peck AB \& Cornelius JG 2000 Reversal of insulin-dependent diabetes using islets generated in vitro from pancreatic stem cells. Nature Medicine 6 278-282.

Rau K, Muglia L \& Locker J 1989 Insulin-gene expression in extrafetal membranes of rats. Diabetes 38 39-43.

Ryan EA, Lakey JRT, Rajotte RV, Korbutt GS, Kin T, Imes S, Rabinovitch A, Elliott JF, Bigam D, Kneteman NM, Warnock GL, 
Larsen I \& Shapiro AM 2001 Clinical outcomes and insulin secretion after islet transplantation with the Edmonton Protocol. Diabetes 50 710-719.

Sang U H, Alilain W \& Saljooque F 2002 Fetal brain progenitor cells transdifferentiate to fates outside the nervous system. Molecular Endocrinology 16 2645-2656.

Scharfmann R 2000 Control of early development of the pancreas in rodents and humans: implications of signals from the mesenchyme. Diabetologia 43 1083-1092.

Seaberg RM, Smukler SR, Kieffer TJ, Enikolopov G, Asghar Z, Wheeler MB, Korbutt G \& van der Kooy D 2004 Clonal identification of multipotent precursors from adult mouse pancreas that generate neural and pancreatic lineages. Nature Biotechnology 22 1115-1124.

Segev H, Fishman B, Ziskind A \& Itskovitz-Eldor J 2004 Differentiation of human embryonic stem cells into insulin producing clusters. Stem Cells 22 265-274.

Shapiro AM, Lakey JR, Ryan EA, Korbutt GS, Toth E, Warnock GL, Kneteman NM \& Rajotte RV 2000 Islet transplantation in seven patients with Type 1 diabetes mellitus using a glucocorticoid-free immunosuppressive regime. New England Journal of Medicine 343 230-238.

Shiroi A, Yoshikawa M, Yokota H, Fukui H, Ishizaka S, Tatsumi K \& Takahashi Y 2002 Identification of insulin-producing cells derived from embryonic stem cells by zinc-chelating dithizone. Stem Cells 20 284-292.

Sipione S, Eshpeter A, Lyon JG, Korbutt GS \& Bleackley RC 2004 Insulin expressing cells from differentiated embryonic stem cells are not beta cells. Diabetologia 47 499-508.

Soria B, Roche E, Berná G, León-Quinto T, Reig JA \& Martin F 2000 Insulin-secreting cells derived from embryonic stem cells normalize glycemia in streptozotocin-induced diabetic mice. Diabetes 49 157-162.

Suzuki A, Zheng Y-W, Kaneko S, Onodera M, Fukao K, Nakauchi $\mathrm{H} \&$ Taniguchi H 2002 Clonal identification and characterization of self-renewing pluripotent stem cells in the developing liver. Journal of Cell Biology 156 173-184.
Swenne I 1992 Pancreatic beta-cell growth and diabetes mellitus. Diabetologia 35 193-201.

Tang D-Q, Cao L-Z, Burkhardt BR, Xia C-Q, Litherland SA, Atkinson MA \& Yang L-J 2004 In vivo and in vitro characterization of insulin-producing cells obtained from murine bone marrow. Diabetes 53 1721-1732.

Tropepe V, Hitoshi S, Sirard C, Mak TW, Rossant J \& van der Kooy D 2001 Direct neural fate specification from embryonic stem cells: a primitive mammalian neural stem cell stage acquired through a default mechanism. Neuron 30 65-78.

Tuch BE, Szymanska B, Yao M, Tabiin MT, Gross DJ, Holman S, Anne Swan M, Humphrey RKB, Marshall GM \& Simpson AM 2003 Function of a genetically modified human liver cell line that stores, processes and secretes insulin. Gene Therapy 10 490-503.

Wilson ME, Scheel D \& German MS 2003 Gene expression cascades in pancreatic development. Mechanisms of Development 120 65-80.

Yang X, Kow L-M, Funabashi T \& Mobbs CV 1999 Hypothalamic glucose sensor. Diabetes 48 1763-1772.

Yang L, Li S, Hatch H, Ahrens A, Cornelius JG, Petersen BE \& Peck AB 2002 In vitro trans-differentiation of adult hepatic stem cells into pancreatic endocrine hormone-producing cells. PNAS 99 8078-8083.

Zalzman, M, Gupta S, Giri R, Berkovich I, Sappal BS, Karnieli O, Zern MA, Fleischer N \& Efrat S 2003 Reversal of hyperglycaemia in mice by using human expandable insulin-producing cells differentiated from fetal liver progenitor cells. PNAS $\mathbf{1 0 0}$ 7253-7258.

Zulewski H, Abraham EJ, Gerlach MJ, Daniel PB, Moritz W, Muller B, Vallejo M, Thomas MK \& Habener JF 2001 Multipotential nestin-positive stem cells isolated from adult pancreatic islets differentiate ex vivo into pancreatic endocrine, exocrine, and hepatic phenotypes. Diabetes 50 521-533.

Received 9 September 2004

Accepted 6 October 2004

Made available online as an Accepted Preprint 18 October 2004 